\title{
Comparative Clinical Study of the Effectiveness of MEKRITEN in Patients with Chronic Suppurative Otitis
}

\author{
Kronik Süpüratif Otitis Medialı Hastalarda MEKRITEN Etkinliğinin \\ Karşılaştırmalı Klinik Çalışması
}

\author{
(D) Abror MUKHITDINOV*, (D) Nemat OLIMOV, (D) Shirinkhan OLIMOVA \\ Tashkent Pharmaceutical Institute, Department of Pharmaceutical Chemistry, Tashkent, Uzbekistan
}

\begin{abstract}
Objectives: Chronic suppurative otitis media (CSOM) is a serious disease with the presence of bacterial infection in the middle ear. Worldwide, $1 \%$ to $46 \%$ of the population living in developed and developing countries have CSOM, about $65-330$ million people, $60 \%$ of whom have significant hearing loss. The study of the wound healing efficacy and tolerability of the drug MEKRITEN (garlic extract liquid) was performed to identify the possibility of issuing recommendations for the drug for clinical use in the Republic of Uzbekistan.

Materials and Methods: The main group of patients, who received the study drug, consisted of 30 patients; the group of patients who received the comparison drug comprised 20 patients. Patients of the main group (30 persons) were given 'garlic extract liquid,' which was developed by the Tashkent Pharmaceutical Institute, given as 2 drops twice per day for 10 days in the external auditory canal. Patients in the comparison group (20 people) took other drugs ( $0.25 \%$ solution of levomycetin) in a similar way. Patients were examined and observed carefully to determine the severity of symptoms such as pain, secretion (in points), and clinical analyses were performed including general blood analysis, and urine. In addition, the researchers performed biochemical (ALT, AST, bilirubin), instrumental (ultrasound of the liver), and special (biopsy of fibrous tissue of echinococcal capsules) analyses.

Results: The average rating of the tolerability and effectiveness in the points for MEKRITEN made portability of 4.97 points, and the effectiveness was 4.77 points, and for $0.25 \%$ levomycetin solution, they were 4.8 and 3.35 points, respectively. While receiving MEKRITEN, no adverse effects and allergic reactions were observed. No criteria for treatment cessation were observed (adverse effects, ineffective treatment, poor adherence to protocol, and refusal to continue) thus the study was not stopped in any patients.

Conclusion: Local therapy with the drug MEKRITEN in patients with CSOM is more effective than local application of $0.25 \%$ levomycetin solution. Local therapy with MEKRITEN in the treatment of CSOM leads to faster termination of otorrhoea and is accompanied by fewer adverse drug reactions.
\end{abstract}

Key words: MEKRITEN, levomycetin, chronic suppurative otitis media, garlic extract liquid

\section{öz}

Amaç: Kronik süpüratif otitis media (KSOM), orta kulakta bakteri enfeksiyonu bulunan ciddi bir hastalıktır. Dünya çapında, gelişmiş ve gelişmekte olan ülkelerde yaşayan nüfusun \%1-46'sı, yaklaşık 65-330 milyon insan, KSOM'dan muzdarip olup, bunların \%60'ında ise önemli işitme kaybı vardır. Özbekistan Cumhuriyeti'nde klinik kullanım için ilaç önerileri verme olasılığını belirlemek için MEKRITEN (sarımsak özü sıvısı) ilacın yara iyileşme etkinliği ve tolere edilebilirliği araștırılmıştır.

Gereç ve Yöntemler: Çalışma ilacını alan ana grup 30 hastadan, karşılaştırma ilacı alan hasta grubu 20 hastadan oluşmaktadır. Ana grubun (30 kişilik) hastalarına, Taşkent İlaç Enstitüsü tarafından geliştirilen sarımsak özü sıvısı 10 gün süreyle dış kulak yolu kanalına günde 2 damla olarak verildi. Karşılaştırma grubundaki hastalar (20 kişi) benzer şekilde diğer ilaçları (\%0.25 levomisetin çözeltisi) aldı. Hastalar, ağrı, sekresyon (puan olarak) gibi şikayetlerin ciddiyetini belirlemek için dikkatli bir şekilde incelendi ve genel kan ve idrar analizi dahil olmak üzere klinik analizler yapıldı. Ayrıca gözlemciler biyokimyasal (ALT, AST, bilirubin), enstrümantal (karaciğer ultrasonu) ve ekineokoksik kapsüllerin fibröz dokusunun biyopsi analizlerini inceledi.

*Correspondence: E-mail: author.uzb@mail.ru, Phone: +998903380568 ORCID-ID: orcid.org/0000-0003-1468-9681

Received: 19.01.2017, Accepted: 18.05.2017

๑Turk J Pharm Sci, Published by Galenos Publishing House. 
Bulgular: MEKRITEN puanlarındaki tolere edilebilirlik ve etkililiğin ortalama derecelendirmesi, 4.97 puanlık taşınabilirlik ve 4.77 puanlık etkililiği $\% 0.25^{\prime}$ lik levomisetin çözeltisi için sırasıyla 4.8 ve 3.35 olarak bulunmuştur. MEKRITEN alınırken yan etki ve alerjik reaksiyon gözlenmedi Tedavi kesilmesi için herhangi bir kriter gözlenmedi (yan etkiler, etkisiz tedavi, protokole uyumsuzluk ve devam etmeyi reddetme) bu nedenle hiçbir hastada çalışma durdurulmadı.

Sonuç: KSOM hastalarında MEKRITEN ile yapılan lokal terapi, \%0.25'lik levomisetin solüsyonunun lokal uygulanmasından daha etkilidir. KSOM tedavisinde MEKRITEN ile lokal terapi, otorri'nin daha hızlı sonlanmasına yol açar.

Anahtar kelimeler: MEKRITEN, levomisetin, kronik süpüratif otitis media, sarımsak özü sıvısı

\section{INTRODUCTION}

Chronic suppurative otitis media (CSOM) is a serious disease with the presence of bacterial infection and perforated tympanic membrane with persistent drainage from the middle ear. It is a major cause of acquired hearing impairment in children, especially in developing countries. Most approaches to treatment have been unsatisfactory or are very expensive and difficult; for example, parenteral aminoglycosides require long hospitalization and are potentially ototoxic.' The pathologic process in chronic purulent otitis media leads to destruction of bone structures of the middle ear and causes hearing loss. Despite the use of antibacterial therapy, CSOM remains the main cause of hearing loss. ${ }^{2}$

CSOM is one of the most urgent problems of otorhinolaryngology because it is a significant part of the whole pathology of ear, nose and throat (ENT) organs, and ranks second in the structure of otorhinolaryngology morbidity. Prevalence surveys, which differ widely in disease definition, sampling methods, and methodologic quality, show that the global burden of illness from CSOM involves 65-330 million individuals with draining ears, $1 \%$ to $46 \%$ of the population of developed and developing countries have CSOM, $60 \%$ of whom suffer important hearing impairment. Annually, 31 million new cases of CSOM are registered in the world, $22.6 \%$ of which are diagnosed in children aged under 5 years. In 30.82 cases per 10,000, the disease is accompanied by hearing loss. Worldwide, 28,000 people die from complications of CSOM every year, mostly from intracranial complications. ${ }^{2}$

Among all chronic diseases of ENT organs, CSOM is the most frequent pathology (up to $48.8 \%$ ). Among patients with ENT pathology who are assisted in the ENT departments, 5.7-7\% have CSOM. CSOM with frequent exacerbations is the cause of ontogeny complications that currently appear in 3.2\% patients, intracranial complications are observed in $1.97 \%$ (e.g., meningitis, brain abscess) and extracranial complications in $1.35 \%$ (e.g., subperiosteal abscess, labyrinthitis). Mortality from CSOM is $16-30 \%$. One of the reasons of the development of destruction in the middle ear is cholesteatoma, which is found in $24-63 \%$ of patients with CSOM at any location of the perforation of the eardrum. Both acute and CSOM are still one of the most common diseases of ENT organs, ranging from 5.1 to $58 \%$ of cases, and are the cause of high levels of hearing loss in 8.6 to $37 \%$ of cases. ${ }^{3,4}$

The issues of early diagnosis, choice of treatment, and characteristics of patients with CSOM are still relevant. However, the solution for these problems is closely connected with the study of various aspects of the etiopathogenesis of the disease, including general and local immunologic reactivity, the state of the antioxidant system of the organism, i.e. the background, where there is probably a pathologic process.

In connection with the above, the efficacy of oil extract of garlic, which was developed by the Tashkent Pharmaceutical Institute, was investigated. In preclinical studies, the drug showed high efficacy in experimental models.

Purpose: To study the wound healing efficacy and tolerability of the drug 'garlic extract liquid' developed by the Tashkent Pharmaceutical Institute, Uzbekistan, and to identify the possibility of issuing recommendations for the drug for clinical use in the Republic of Uzbekistan (RUz).

\section{MATERIALS AND METHODS}

This study was open, full designed, and performed on two parallel groups. The main group of patients that received the new drug consisted of 30 patients. The second group of patients, which received the comparison drug, comprised 20 patients. The groups were matched by sex, age, and diagnosis. Patients of both sexes receiving outpatient treatment, aged over 18 years, and who gave written informed consent for participation in the research, and those who underwent surgery in the middle ear (myringoplasty) were included in the study. ${ }^{2}$

The criteria for exclusion were patients aged less than 18 years, pregnancy, lactation, the presence of hypersensitivity to the drug component, participation in other clinical trials within the last 30 days, no written informed consent for participation in clinical research, and contraindications to the use of the drug.

\section{Patient details}

The first group included 30 patients with a mean age of $34 \pm 12.33$ years; 13 patients were women and 17 were men. Eight patients were diagnosed as having right-sided CSOM, 11 patients were hospitalized with left CSOM, and the remaining 11 patients had bilateral CSOM.

Second group consisted of 20 patients and their average age was $35 \pm 13.42$ years. Twelve patients were female and 8 were male. Ten patients were diagnosed as having right-sided CSOM, 6 had left CSOM, and 4 patients were treated for bilateral CSOM.

\section{The scheme of drugs appointment}

Patients of the main group ( 30 persons) were given garlic extract liquid. The medication was given as 2 drops twice per day for 10 days in the external auditory canal. Patients in the comparison group (20 people) took other drugs ( $0.25 \%$ levomycetin solution) in a similar way. Simultaneous complementary therapies were not performed. Other drugs with a similar action were excluded. 
Medications and other drugs that are compatible with the drug, as well as the necessary physical therapy, were used for the necessary treatment of the underlying disease.

\section{The overall schedule of the research}

- After the initial examination of patients who met the inclusion criteria, in order to obtain their written informed consent to participate in the study, the patients were provided with information about the experimental drug 'garlic extract liquid,' information about doses, schemes, routes of administration, and period of treatment.

- When the patients' written consent for participation in the research was obtained, they were administered the study drug or the comparison drug.

- The starting point of the patient's participation in the study: the first day of receiving study drug or the comparison drug.

- Treatment was described in all patients included in the study.

- Any treatment related to concomitant diseases was registered in the medical history and individual registration form.

The patient was provided with the informed consent form for participation in a clinical trial. The patient had enough time for decision-making. The patient signed the informed consent. Procedures for verification of patient compliance of doctor orders are governed by the internal regulations of hospital, where the study was conducted. If there was a break in the procedure of taking the drug, the patient was excluded from the study. ${ }^{3}$

Responsible person will not allow the use of the test drug and comparison drug for any other purpose except that specified in the protocol of a clinical trial.

After the completion of the study, a report on the use of the test drug and comparison drug was made using Form 2 of Appendix No: 2 to the order of Ministry of Health (MH) of the RUz No: 334 , dated: 25.07.2001.

\section{Examination}

Patients were examined and observed carefully to determine the severity of symptoms such as pain, secretion (in points); and clinical analyses were checked, including general blood analysis and urine. In addition, the researchers performed biochemical (alanine aminotransferase, aspartate transaminase, bilirubin), instrumental (ultrasound of the liver) and special (biopsy of fibrous tissue of echinococcal capsules) analyses.

Criteria for evaluating the effectiveness of the study drug The list of performance indicators:

- The complete disappearance of the inflammatory process and pain,

- Normalization of laboratory and instrumental studies.

Evaluation of the effectiveness of an investigational drug was conducted by the researcher on the basis of the above criteria in points according to the following scale (Table 1):

Methods and timing of assessing, recording, and statistical processing of performance indicators:

Registration of the performance indicators was conducted
Table 1. Criteria for an assessment of efficiency of the study drug

A marked disappearance of symptoms: no pain and secretions (points 3 points High efficiency $0-2$ ), Normalization of the indicators of laboratory and instrumental studies at the end of the test.

Moderate disappearance of symptoms: moderate pain reduction and secretions (points 3-4), 2 points Reasonable efficiency a moderate improvement in the indicators of laboratory and instrumental studies at the end of the test.

The disappearance of minor symptoms: a small decrease in pain and secretions (points 5-6), a slight improvement of indicators of laboratory and instrumental studies at the end of the test.

No change or worsening 0 point Lack of efficiency of clinical and laboratory parameters at the end of treatment.

immediately after examination and/or receipt of laboratory data. The information expressed in a quantitative form was subjected to statistical processing, including the use of special software.

Student's t-test is assumed for the application of methods of variation statistics. If necessary, multivariate analysis was performed. ${ }^{4}$

\section{Criteria for assessing the tolerability of the study drug}

Tolerability was assessed on the basis of subjective symptoms and sensations reported by the patient, and objective data obtained by the researcher in the treatment process. The dynamics of laboratory indicators and the incidence and nature of adverse reactions were taken into account.

Tolerability was assessed and scored by the researcher and patients (Table 2).

\section{RESULTS}

Efficacy: analysis of efficacy was performed on the results of the study on patients receiving the drug according to the scheme provided in this protocol.

The results are provided in Table 3.

Tolerability: When analyzing adverse effects, it is necessary to exclude adverse effects that might occur from taking other medications or treatment procedures prescribed to the patient along with the test drug. If there is uncertainty, this case can only be partly analyzed regarding intolerance. 
The average rating of the tolerability and effectiveness for MEKRITEN found portability as 4.97 points, and the effectiveness as 4.77 points, compared with $0.25 \%$ levomycetin solution at 4.8 and 3.35 points, respectively (Table 4).

Neither drug had any adverse effects on the blood according to a general analysis.

Table 2. Assessment of tolerability of patients to the study drug (in points)

During objective examination and/or laboratory research

4 points in the dynamics any pathologic changes or clinically significant deviations are not revealed and/or a patient does not note adverse reactions

During objective examination and/or laboratory research in the dynamics minor changes are revealed that

3 points are transient in nature and do not require change of treatment with investigational drugs and/or a patient notes symptoms of minor adverse reactions, which are not causing serious problems.

During objective examination and/or laboratory, research in the dynamics significant changes are 2 points revealed that do not require additional measures and/ or a patient notes an adverse reaction, which has a negative impact on his condition, but does not require discontinuation of the drug.

During objective examination and/or laboratory research in the dynamics substantial changes are revealed,

1 point and/or the patient notes an adverse reaction which has negative effects on his condition and require discontinuation of the drug

During objective examination and/or laboratory research in the dynamics significant changes are revealed and/

0 point or the patient notes an adverse reaction requiring discontinuation of the drug and additional medical measures

Table 3. Efficacy of MEKRITEN

\begin{tabular}{lllll}
\multirow{2}{*}{ Indicator } & \multicolumn{2}{l}{ MEKRITEN } & \multicolumn{2}{l}{ Levomycetin } \\
\cline { 2 - 5 } & Before & After & Before & After \\
\hline Pain & 0.033 & 0 & 0 & 0 \\
\hline Secretions & 2.27 & 0 & 2.35 & 0.9
\end{tabular}

\section{Monitoring, audit and inspection}

In the study, monitoring and auditing is made by the Customer; during the study and at the end of it inspection from the Pharmacological Committee of the $\mathrm{MOH}$ and GDQCM (General Directorate for Quality Control of Medicines) of the RUz is possible.

The form of release - in bottles.

\section{Information about "MEKRITEN"}

Preparation of Garlic Extract contains the oil extract of garlic as the active substances. Release form - in bottles. Storage conditions - In a dry, cool place. Shelf life - 2 years. Preparation for research and the preparation of the comparison is provided by the Contractor to the Customer free of charge. Test samples should not be used otherwise than for specified clinical studies. While receiving MEKRITEN, no side effects and allergic reactions were observed.

\section{Report registration}

All authors hereby declare that all experiments have been examined and approved by the appropriate ethics committee and have therefore been performed in accordance with the ethical standards laid down in the 1964 Declaration of Helsinki. Clinical and analytical data obtained during this study should be evaluated and presented spreadsheets, and then summarized and discussed in the report prepared in accordance with Annex 2 to the order MOH of RUz No: 334 dated 25 July 2001. This study was investigated and approved by Clinical Ethical Committee of $\mathrm{MOH}, \mathrm{RUz}$ and registered N.16/2 with the date of 02.05.2014.

\section{Record keeping}

Clinical trial documents in accordance with the list of documents of clinical trials that must be stored in a clinical database (addon 4. to the item 5.3 of the Annex No: 1 to the Order of MH of the Rep Uzb. No: 334 dated 25 July 2001) should be retained for at least 15 years.

\section{Statistical analysis}

All the parameters measured are expressed as means \pm standard deviation. The difference between the mean values was analyzed using Student's t-test at the $5 \%$ significance level. $P<0.05$ was considered to be significant, and $p>0.05$ was non-significant.

Table 4. Changes of indicators of general blood analysis with MEKRITEN and $0.25 \%$ levomycetin

\begin{tabular}{|c|c|c|c|c|c|}
\hline \multirow{2}{*}{ No } & \multirow{2}{*}{ Indicators } & \multicolumn{2}{|l|}{ MEKRITEN } & \multicolumn{2}{|c|}{ Levomycetin } \\
\hline & & Before & After & Before & After \\
\hline 1 & Hemoglobin & $113.4 \mathrm{~g} / \mathrm{l}$ & $115.4 \mathrm{~g} / \mathrm{l}$ & $114.4 \mu / l$ & $114.4 \mathrm{~g} / \mathrm{l}$ \\
\hline 2 & Erythrocyte & $4.14 \times 10^{12} / 1$ & $4.19 \times 10^{12} / 1$ & $4 \times 10^{12} / 1$ & $3.9 \times 10^{12} / 1$ \\
\hline 3 & Leukocyte & $8.93 \times 10^{9} / 1$ & $5.73 \times 10^{9} / 1$ & $8.9 \times 10^{9} / 1$ & $7.7 \times 10^{9} / 1$ \\
\hline 4 & ESR & $7.07 \mathrm{~mm} / \mathrm{h}$ & $5.13 \mathrm{~mm} / \mathrm{h}$ & $7 \mathrm{~mm} / \mathrm{h}$ & $6 \mathrm{~mm} / \mathrm{h}$ \\
\hline
\end{tabular}

ESR: Erythrocyte sedimentation rate 


\section{DISCUSSION}

Garlic has been known for some time to have anti-infective properties against a wide range of microorganisms. ${ }^{1}$ The present study has further demonstrated the antimicrobial potency of 'garlic extract liquid' against local multidrug-resistant bacteria and Candida isolates from Uzbekistan. The results of the patients using the brand-new drug MEKRITEN and levomycetin were comparable, thus showing that the isolates exhibited susceptibility. This indicates that 'garlic extract liquid' has a broad spectrum of antimicrobial activity and a wide therapeutic window. The isolates tested in this study are responsible for many diseases in Uzbekistan, including bacterial meningitis, maxillary sinusitis, and otolaryngologic diseases by $S$. pneumoniae, $H$. influenza and S. pyogenes, ${ }^{2}$ bronchopulmonary disorders and CSOM by Pseudomonas aeruginosa, ${ }^{3}$ candidiasis and vaginitis by Candida albicans, ${ }^{4}$ nosocomial infections and bacteremia due to multidrug-resistant staphylococcal infections and diarrheal diseases caused by Escherichia coli, Shigella spp. (S. dysenteriae, S. flexneri, S. boydii and S. sonnei) and Salmonella typhimurium. $^{2,5}$ The sensitivity of these isolates to 'garlic extract liquid' also suggests that the intrinsic biosubstances in this extract are naive to the various drug resistance factors of the isolates, which include beta-lactamase expression, increased pyrrolidonylarylamidase activity, aminoglycosidemodifying enzymes, and altered ribosomal binding. ${ }^{5}$ Meanwhile, the antimicrobial potency of garlic has been attributed to its ability to inhibit toxin production and expression of enzymes for pathogenesis., ${ }^{1,5}$ Several studies previously demonstrated the antibacterial potency of 'garlic extract liquid' against enteropathogens such as Vibrio parahaemolyticus, E. coli, Klebsiella pneumonia; Proteus spp. ( $P$. mirabilis, $P$. vulgaris, $P$. penneri, and $P$. hauseri); and Staphylococcus aureus, ${ }^{6}$ and anticandidal effects against Candida spp. (C. albicans, C. glabrata, C. parapsilosis, C. tropicalis and C. crusei. ${ }^{7}$ In spite of geographic variation, 'garlic extract liquid' for our isolates are consistent with those of Sivam, ${ }^{8}$ but are relatively lower than values obtained in the literature. ${ }^{9}$ This antimicrobial potency disparity of garlic has been attributed to the different concentrations of individually and synergistically active biosubstances in garlic preparations coupled with their interactions with sulfhydryl agents in culture media. This phenomenon has been used to explain the stronger antimicrobial effect of allicin than garlic oil disulfides. ${ }^{10}$ Allicin and other diallyl sulfide compounds have been found at different concentrations in MEKRITEN determined by age and method of extract preparation. It can be said that the concentration at which 'garlic extract liquid' showed growth inhibition was also fungicidal to our isolates because it displayed comparable MEKRITEN and nystatin values. The susceptibility response observed of some of the $P$. aeruginosa isolates aligns with the finding ${ }^{10}$ but at variance with the work of Kivanc and Kunduhoglu. ${ }^{11}$ The significantly increased minimum inhibitory concentration at 48 hours postinoculation may be the consequence of colony-forming unit rebound and the bacteriostatic effect of garlic extract liquid on these strains. The reliability of the clinical interpretation of this observation may undoubtedly require further tolerability testing of 'garlic extract liquid' in humans as a prelude to understanding garlicinduced plasma resistance to infections. The observation that 'garlic extract liquid' elicited its antimicrobial potency in a dose- and time-dependent manner producing distinct time-kill profiles suggests variations in the growth inhibitory responses of the tested isolates to garlic. Similar responses have been observed and surveyed in antibiotic-resistant Escherichia coli, Enterobacter cloacae, and Citrobacter freund. ${ }^{12}$ However, the uniqueness of time-kill profiles of Gram-positive and Gramnegative bacteria may be connected with their structurally different cell wall barriers. The lipid composition of the cell wall has been found to have an influence on the permeability of hydrophobic and volatile bioactive substances in garlic. ${ }^{13}$ The eukaryotic nature and ergosterol availability in Candida cell walls may also be crucial to the observed time-kill kinetics of 'garlic extract liquid' against our isolates. ${ }^{14}$

\section{CONCLUSIONS}

Local therapy with the drug MEKRITEN (garlic extract liquid) in patients with CSOM is more effective than local application of $0.25 \%$ levomycetin solution. Local therapy with MEKRITEN in the treatment of CSOM leads to faster termination of otorrhoea and is accompanied by fewer adverse drug reactions.

According to the results of clinical trials, ototoxic properties of the drug MEKRITEN in patients were not identified. The drug is well tolerated. MEKRITEN is fully comparable to levomycetin. Thus, MEKRITEN is effective in the treatment of CSOM and is recommended for medical use in the RUz.

\section{ACKNOWLEDGEMENTS}

This study was supported by Tashkent Pharmaceutical Institute, Tashkent, RUz. We also thank junior scientific researcher Bekhzod Abdullaev, who is a student of Tashkent Medical Academy, for his help in initiating the study, the artwork performed in the manuscript and the English correction.

Conflict of Interest: No conflict of interest was declared by the authors.

\section{REFERENCES}

1. Acuin J, Smith A, Mackenzie I. Treatments for chronic suppurative otitis media. Cochrane Database Syst Rev. 2000:CD000473.

2. Borek C. Antioxidant health effects of aged garlic extract. J Nutr. 2001;131:1010-1015.

3. Kleijnen J, Knipschild P, Riet GT. Garlic, onions and cardiovascular risk factors: a review of the evidence from human experiments with emphasis on commercially available preparations. $\mathrm{Br} \mathrm{J}$ Clin Pharmacol. 1989;28:535-544.

4. Pattanayak SP, Sunita P. Wound healing, anti-microbial and antioxidant potential of Dendrophthoe falcata (L.f) Ettingsh. J Ethnopharmacol. 2008;120:241-247.

5. Kasuga S, Uda N, Kyo E, Ushijima M, Morihara N, Itakura Y. Pharmacological activities of aged garlic extract in comparison with other garlic preparations. J Nutr. 2001;131:1080-1084. 
6. Ako-Nai AK, Ikem IC, Aziba A, Ajayi AA, Onipede OA. Bacteriological examination of chronic osteomyelitis cases in Ile-lfe, Southwestern Nigeria. Afr J Clin Exp Microbiol. 2003;4:41-51.

7. Lawson LD, Wood SG, Hughes BG. HPLC analysis of allicin and other thiosulfinates in garlic clove homogenates. Planta Med. 1991;57:263-270.

8. Yin MC, Chang HC, Tsao SM. Inhibitory effects of aqueous garlic extract, garlic oil and four diallylsulphides against four enteric pathogens. J Food Drug Anal. 2002;10:120-126.

9. Kumar A, Sharma VD. Inhibitory effect of garlic (Allium sativum Linn) on enterotoxigenic Escherichia coli. Indian J Med. 1982;76(Suppl):66-70.

10. Lawson DL. The composition and chemistry of garlic cloves and processed garlic. In: Koch HP, Lawson DL, eds. Garlic The Science and
Therapeutic Applications of Allium sativum L and Related Species, 2nd ed. Williams and Wilkins; Baltimore; 1996:37-107.

11. Kivanc M, Kunduhoglu B. Antimicrobial activity of fresh plant juice on the growth of bacteria and yeasts. J Qafqaz University. 1997;1:27-35.

12. Obi CL, Enweani IB, Giwa JO. Bacterial agents causing chronic suppurative otitis media. East Afr Med J. 1995;72:370-372.

13. Tsao SM, Yin M. In vitro activity of garlic oil and four sulphides against antibiotic-resistant Pseudomonas aeruginosa and Klebsiella pneumoniae. J Antimicrob Chemother 2001;47:665-670.

14. Lawson LD. Garlic: a review of its medicinal effects and indicated active compounds. In: Lawson LD, Bauer R, eds. ACS Symposium Series 691: Phytomedicines of Europe: Chemistry and Biological Activity. American Chemical Society. Washington DC; 1998:176-209. 